\title{
Study of sewage sludge use in agriculture and its effect on plant and soil
}

\author{
Hussein Kh. Ahmed*, Hassan A. Fawy** and E.S.Abdel-Hady* \\ * Soils and Water Dept., Faculty of Agric., Al-Azhar Univ. Cairo, Egypt \\ ** Soil Fertility and Microbiology Dept., Desert Research Center (DRC), Cairo, Egypt
}

\begin{abstract}
The plant macro and micro nutrients as well as organic matter make sludge disposal in soil an attractive option. Nitrogen has received most attention and it is normally the most abundant sludge nutrient. One of the best alternatives to waste disposal is through the soil-plant system as a fertilizer. Based on properties different wastes can be co-recycled in order to take simultaneously the best profit and minimize environmental pollution .An experiment was carried out with a calcareous soil. Using six different doses of a sewage sludge were treated. A crop barley (Hordium Vulgare, Giza 123 ) was grown in the amended soils. The application of sewage sludge to the calcareous soil lowered the $\mathrm{pH}$ of the soil, although the value always around 7.757.9 at the end of the experiment. In the barley plants it was observed that the higher the yield, the higher the nitrogen contents. Electrical conductivity rose with organic amendment. Also it improved the nutrient level of the soil, particularly nitrogen and available phosphorus.
\end{abstract}

Keywords: sewage sludge, macro and micro nutrients , agriculture , organic matter, soil, plant.

\section{INTRODUCTION}

There is an increasing interest in the agricultural application of sludge obtained in wastewater treatment plants, due to the possibility of recycling valuable components;organic mtter, nitrogen ,phosphorus and other plant nutrients (Sommers, 1977; Chaussed et al,1978;Suss,1979).

Sewage sludge is the insoluble residue from wastewater treatment after either aerobic or anaerobic digestion processes.Sludge comprises resistant compounds (65\% organic matter),nitrogen (3\%),phosphorus $\left(2 \% \mathrm{P}_{2} \mathrm{O}_{5}\right)$, other macronutrients $\left(0.5 \% \mathrm{~K}_{2} \mathrm{O}, 5 \% \mathrm{CaO}, 1.5 \% \mathrm{MgO}\right)$ a wide range of macronutrient and nonessential trace elements,organic micropollutants, microorganisms and eggs of parasitic organisms. The substantial nitrogen and phosphorus concentration in sludge render is a useful fertilizer material and its organic constituents give it beneficial soil conditioning properties. The improved aeration and drainage following sludge amendments have indirect effects on the soil-plant relationships of heavy metals through affecting growth,nodulation in leguminous plants and other properties (Heckman et al,1986;Roberts et al 1988). Dahdoh et al (1997) reported that, the effect of adding sewage sludges rates to calcareous loam and loamy soils,irrigated with waters of differing salinity using broad bean plants. The results shows a significant increase of broad bean yield when using sewage sludge up to $2 \%$ in calcareous loam irrigated by tap water or saline water but the yield under tap water irrigation is always higher.Addition of sewage sludge to the loamy soil increased the yield under tap water irrigation,while decreased with saline water.Also, Rabia et al (1997) studied the effect of sewage sludge and different rates of dried sewage sludge on Faba bean followed by Sorghum growing on sandy soil.

The effect of sewage sludge application to a desert soil on nodulation, nitrogen fixation and plant growth was investigated in a pot experiment under greenhouse conditions.Plant analysis indicated that the inhibitory effect of sewage sludge at high application rates was most probably due to atoxic effect of heavy metals on the microsymbiont rather than on host plants.It is concluded that sewage sludge at low application rates may significantly improve legume growth in desert soils (Abd-Alla et al (1999) ).Evaluation of the utilization of treated sewage water in irrigation and its effect on some soil physical and chemical characteristics and the productivity of sorghum Fodder (Aljunied (2007)). The results of the column study indicated that the application of sewage decreased the $\mathrm{pH}$ of the leachate, while fly ash increased the $\mathrm{pH}$.Whereas the solid wastes increased the leachate salinity in both in red and black soil.Application of solid wastes in soils did not results in appreciable concentration of potentially toxic heavy metals in the leachate. Alkaine coal fly ash groundwater reacts with water and forms hydration products that are considerably 
different the original constituents of the ash when used for soil amendment and source of nutrient for crop production (Yeledhalli et al(2007) ).

This study revealed that sludge derived organic matter contributed $t i$ the formation of macroaggregates through the binding of preexisting microaggregates. These macroaggregates were thus responsible for the accumulation of trace metals in the coarsest fraction as wellas for the protection of maize derived organic matter agannist biodegradation (Parat et al (2007) ).In general,none of the heavy metals studied in both leaves and seed of crop reached either phytotoxic levels or toxic levels for humans or livestock. The results showed that sewage sludge could be used as nitrogen fertilizer in grain sorghum production (Akdeniz et al (2006)).

On the other hand, since sewage sludge contains high concentrations of potentially elements such as Znic ,Nikal,Cadum and Copper problem way arise when sludge is applied to an agricultural soil (Sanders et al,(4986);Omran and Waly(1988).Heavy metal accumulation in the plant tissues may also occur. The fertility benefit must be balanced against the poten possibility metal contamination through application of sludge to agricultural productive soil.In geberal,it has been shown that the addition of sludge to agricultural soil increase crop production.Dowdy et al (1978) reported that the increase of corp yield by sludge application often exceed that of well-managed fertilized controls.Sewage sludge produced is used for the improvement of soil fertility and plant priduction. Therefore,studies on sludges are important due to the economic and environmental implications of application of these materials to agricultural soils. The present work is trial to describes investigations into the fertilizer $\mathrm{N}$ and $\mathrm{P}$ value of Elgabal-Elasfar sewage sludge use experiments under greenhouse conditions.

\section{MATERIALS AND METHODS}

The soil was used a loamy clay (calcareous) takan from the surface layer of El-Behira Governorate.The sludge was the activated type and was municipal sewage sludge. The soil and sludge samples were air dried and crushed so as to pass a $2 \mathrm{~mm}$ sieve.Then each pot content $7 \mathrm{~kg}$ of sieved soil with various amendments. The physical and chemical characteristics of the sludge and soil are shown in table (1).

Table(1):Some physical and chemical properties and extractable $\mathrm{Fe}, \mathrm{Cu}, \mathrm{Zn}, \mathrm{Mn}, \mathrm{Ni}, \mathrm{Co}$ and $\mathrm{Cd}$ amounts of the soil and sewage sludge.

\begin{tabular}{|c|c|c|c|c|c|c|c|c|}
\hline \multicolumn{7}{|c|}{ ב } & & \\
\hline \multicolumn{2}{|c|}{ Location } & \multicolumn{2}{|c|}{$\begin{array}{c}\text { C.Sand } \\
\text { (\%) }\end{array}$} & $\begin{array}{l}\text { F.Sand } \\
\text { (\%) }\end{array}$ & $\begin{array}{l}\text { Silt } \\
\text { (\%) }\end{array}$ & \multicolumn{2}{|r|}{$\begin{array}{c}\text { Clay } \\
\text { (\%) }\end{array}$} & Texture \\
\hline \multicolumn{2}{|c|}{ Behira } & \multicolumn{2}{|c|}{4.50} & 23.08 & 46.33 & \multicolumn{2}{|r|}{26.09} & L.Clay \\
\hline \multicolumn{9}{|c|}{ B- Chemical properties } \\
\hline $\mathrm{pH}$ & $\begin{array}{c}\mathrm{EC} \\
\mathrm{dS} / \mathrm{m}\end{array}$ & $\begin{array}{c}\text { O.M } \\
\%\end{array}$ & $\begin{array}{l}\text { C } \\
\%\end{array}$ & $\begin{array}{c}\text { CEC } \\
\text { cmolkg }\end{array}$ & $\begin{array}{c}P \\
\mathrm{mg} / \mathrm{kg}\end{array}$ & \multicolumn{2}{|r|}{$\begin{array}{l}\mathbf{N} \\
\%\end{array}$} & $\begin{array}{c}\mathrm{CaCO}_{3} \\
\%\end{array}$ \\
\hline 7.9 & 0.4 & 0.5 & 0.2 & 16.9 & 11.5 & \multicolumn{2}{|r|}{0.11} & 22.6 \\
\hline 7.1 & 2.1 & 23.0 & 12.2 & 55.0 & 455 & \multicolumn{2}{|r|}{1.35} & 2.66 \\
\hline \multicolumn{9}{|c|}{ C-Extractable ions $\mathrm{mg} / \mathrm{kg}$} \\
\hline Locatic & & $\mathrm{Fe}$ & $\mathrm{Cu}$ & $\mathrm{Zn}$ & Mn & $\mathrm{Ni}$ & Co & Cd \\
\hline Behira & & 3.55 & 1.12 & 0.25 & 4.25 & 0.36 & 0.15 & 0.035 \\
\hline S.sludg & & 25.3 & 12.5 & 90.5 & 62.3 & 1.30 & 0.45 & 0.12 \\
\hline
\end{tabular}

Treated sludge nitrogen was compared with inorganic nitrogen (ammonium nitrate ). Four replicates of each nitrogen treatment were assembled as follows:(1) The control pots were unamended.(2) Soils were supplied with $\mathrm{KH}_{2} \mathrm{PO}_{4}$ to yield $40 \mathrm{ppm}$ (No, No+So,So).(3) Soils were supplied with $\mathrm{KH}_{2} \mathrm{PO}_{4}$ to yield $40 \mathrm{ppm}$ and $\mathrm{NH}_{4} \mathrm{NO}_{3}$ to yield $30,60,120,240$ and $480 \mathrm{ppm}\left(\mathrm{N}_{1}, \mathrm{~N}_{2}\right.$ , $\mathrm{N}_{3}, \mathrm{~N}_{4}, \mathrm{~N}_{5}$ ). (4) Soils were supplied with $\mathrm{KH}_{2} \mathrm{PO}_{4}$ to yield 40ppm and $\mathrm{NH}_{4} \mathrm{NO}_{3}$ to yield $15,30,60,120,240$ ppm and sewage sludge was added to soil at 5, $10,20,40$ and $80 \mathrm{t} \mathrm{ha}^{-1}\left(\mathrm{~N}+\mathrm{S}_{1}, \mathrm{~N}+\mathrm{S}_{2}, \mathrm{~N}+\mathrm{S}_{3}, \mathrm{~N}+\mathrm{S}_{4}\right.$ and $\mathrm{N}+\mathrm{S}_{5}$ ).(5) Soils were supplied with $\mathrm{KH}_{2} \mathrm{PO}_{4}$ to yield $40 \mathrm{ppm}$ and sewage sludge was added to soil at 10 , $20,40,80,160$ and $320 \mathrm{t} \mathrm{ha}^{-1}$ chosen to supply amounts of available $\mathrm{N}$ similar to the ammonium nitrate rates $\left(S_{1}, S_{2}, S_{3}, S_{4}, S_{5}\right.$ and $\left.S_{6}\right)$. 
The pots were seeds with barley (Hordium Vulgare,Giza 123 ) , 25 seed per pot and the plants were thinned 20 after germination. The water content of the soil was adjusted to $70 \%$ of fieled capacity .The pots were placed in greenhouse.Three months after seeding ,the plants were harvested for nutrients composition and chemical analysis. Samples were analyzed soil , $\mathrm{pH}$ and Ec were measured in a 1:2.5 water extract ( Richards ,1954); lime was determined according to (Richards 1954 ) ; organic matter by using modified Walkley -Black method (Jackson 1973); CEC was determined by saturation with ammonium acetate at $\mathrm{pH} 7$ (Page et al,1982). Available $\mathrm{P}$ was determined according to (Olsen et al 1965 ) and the content determined by the Murphy and Riley method (Murphy and Riley ,1962 ).Total nitrogen was assessed using the Kjeldahl method ,as specified by ( Bremner ,1965). Soil sample were extracted for available $\mathrm{Fe}, \mathrm{Cu}, \mathrm{Zn}, \mathrm{Mn}, \mathrm{Co}, \mathrm{Ni}$ and $\mathrm{Cd}$ in DTPA solution (0.005M DTPA +0.005 $\mathrm{M} \mathrm{CaCl}_{2}+0.1 \mathrm{M}$ TEA (triethanolamine ) $\mathrm{pH}$ 7.3), (Lindsay and Norvell, 1978). All the solutions of $\mathrm{Fe}, \mathrm{Cu}, \mathrm{Zn}, \mathrm{Mn}, \mathrm{Co}, \mathrm{Ni}$ and $\mathrm{Cd}$ were analyzed by atomic absorption spectrophotometer .

Regarding plant analysis, plant samples were oven dried at $60^{\circ} \mathrm{C}$ to preserve nitrogenous compounds and ground. A sample was wet-digested by Kjeldahl method according to Chapman and Pratt (1965) using sulfuric acid and hydrogen peroxide to determine both $\mathrm{N}$ and $\mathrm{P}$. Nitrogen was measured by titration of ammonia against standard $\mathrm{HCl}$, while $P$ was determined colourimetrically using spectrophotometer.Potassium was determined by flame photometry (Johnson and Ulrich ,4959). Regression analysis and correlation coefficient were recruited to verify the relationship between the different variable responses that were measured in this work (Gomez and Gomez, 1984). Treatments' means were differentiated using the least significant difference (LSD) according to Duncan (1955).

\section{RESULTS AND DISCUUSION}

Current interest in assessing the quality of soil resources has been triggered by increasing awareness ofsoil as a component of the earth's biosphere.Soil has a role not only in production of food and fibe but also in the maintenance of environmental quality. Thus, it is critical to define and evaluate the quality of soil resources. Conceptually, soil quality is defined as the capacity of soil to function within ecosystem noundaries to sustain biological productivity, to maintain quality of the environment and to promote plant and animal health
(Doran and Parkin 1994 ) . Figure(2 a,b,c,d,e,f)shows dry matter production and the macronutrients content barley crops for the various treatments.Observed that the application of sewage sludge enhanced soil fertility and that crop yield in the amended soils was higher than in the control.Phosphorus and potassium were the macronutrients less absorbed by the barley crop.However, nitrogen was the macronutrients most absorbed when sludge was applied to soil .With sewage sludge the low rate of application did not significantly change dry matter production on either of the soils.Tested the heavy textured soil efficiency decreased with increasing rate of sludge.

It can be observed that the contents of total nitrogen in the soil increased when the sewage sludge added ,the largest values of total nitrogen being recorded when the sludges was applied than the inorganic fertilizers. The application sewage sludge resulted in the largest increase of available phosphorus content.The amended soils particularly those to which high doses of sludge (320 t ha $\left.{ }^{-1}\right)$ had been applied showed a higher nitrogen and phosphorus content than the control (Figure 2 e,f ). The same amount of inorganic fertilizer was applied to the soils the differences could be attributed to the organic amensment. This phenomenon can be expected since sewage sludge contains both quantities of proteinic material (Serna and Pomares (1992) ).as can be seen from the high values for nitrogen in figure (2 a,b,c,d) and of polyphosphorated compounds from detergenints. The effects of sludge on barley potassium values were variable but generally small.

The soil $\mathrm{pH}$ is of paramount importance the plant absorption ofheavy metals since it conditions their mobility in soil.According to Pluquet (1984) an increase of one unit in $\mathrm{pH}$ reduces heavy metal absorption by plants by $15 \%$.When sewage sludge (whether or not contaminated by heavy metals) was applied the soil pH decreased in all the cases, but fell by approximately half a unit when the maximum dosage (320 t ha ${ }^{-1}$ ) was used (Figure2 e,f ). Electrical conductivity also varied when the sludge amendment was carried out and it increased compared to the control (Figure2e,f ) due to the formation of metallic salts (complexes of organic matter and heavy metals ). Electrical conductivity of the maximum sludge amended soil was 4.48 times higher than the control .In the soil amended with sewage sludge (especially $\mathrm{S}_{5}$ and $\mathrm{S}_{6}$ dosages) the CEC content significantly increased.There was no significant differences between the control and CEC in nitrogen and 
nitrogen+sludge treatments. The amount of organic matter determined in the soil (Figure 2c,d ) was not significantly different between the control and nitrogen treatment soils. But significant difference in organic matter was found between the control and sludge amended soils.

In general ,in terms of nutritional status the amended soils at the end of the experiment showed higher nitrogen and phosphorus contents than the control soil, but a similar content of cation exchange capacity(CEC), Electrical conductivity (Ec) confirming the theories proposed by several authors (Zucconi and Bertoldi,(1987) ). Thus the yield decrease caused by the heavy metals contained in these materials and to the increased conductivity.

In conclusion ,the sewage sludge used in this study was very poor sources of phosphrous plant growth, primarly because Iran and Aluminum treatments were used to precipitate phosphrous in the sludge phosphrous in the sludge was in organic form so microbial minerililzation had little effect on phosphrous availability.

Figure (2): Effect of different nitrogen and sewage sludge amendments on dry Matter ,nitrogen and phosphorus extracted from plant and total nitrogen,available phosphorus,cation exchange capacity, Electrical conductivity, and $\mathrm{pH}$ from a calcareous soil.

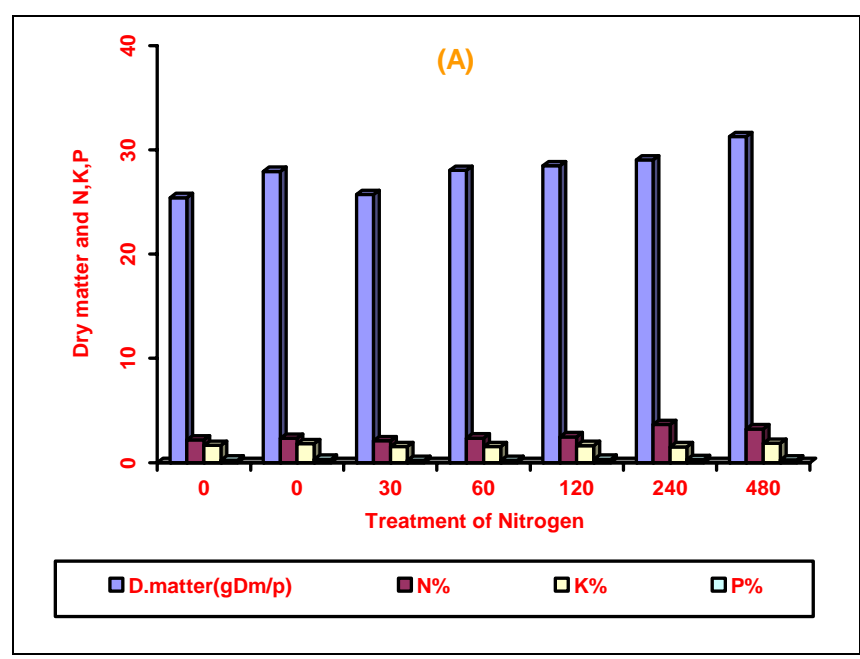

$\mathrm{LSD}_{0.05}$ (D.matter=3.92,N=0.53,K= - , P=0.04 )

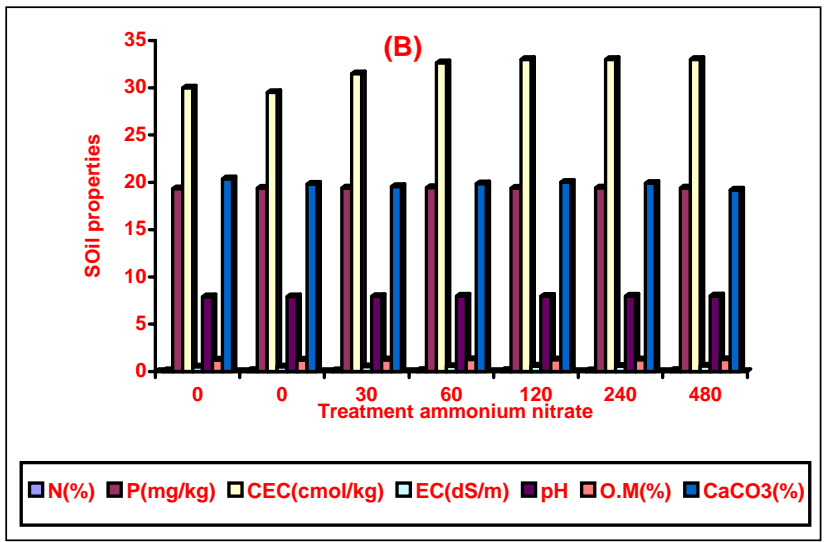

$\operatorname{LSD}_{\text {o.o5 }}(\mathrm{N}=-\mathrm{P}=-\mathrm{P}, \mathrm{CEC}=-$, $\mathrm{Ec}=0.12, \mathrm{pH}=0.36, \mathrm{O} . \mathrm{M}=-, \mathrm{CaCO}=1.01)$

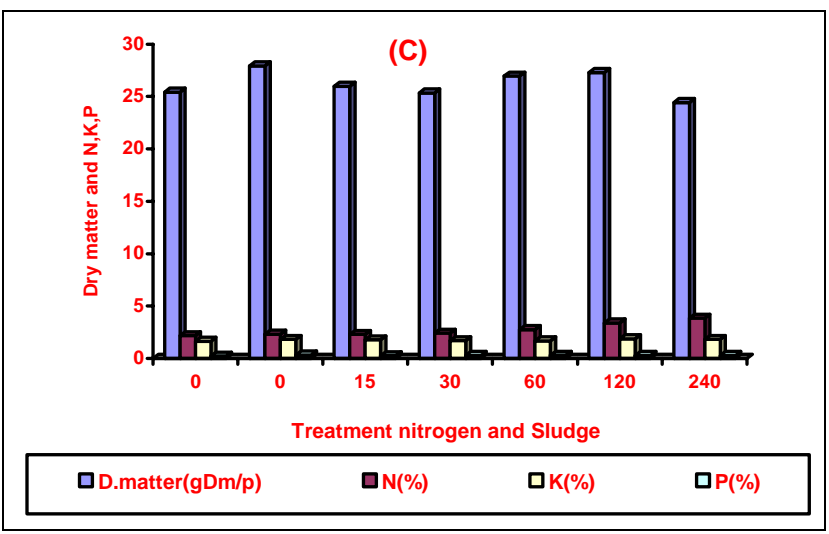

LSD $_{0.05}$ (D.matter=3.32 ,N=0.35, $\mathrm{k}=-, \mathrm{P}=0.4$ )

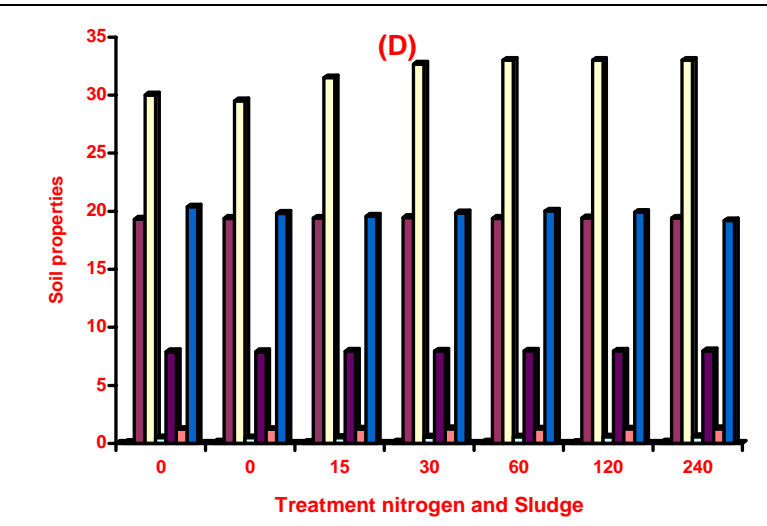

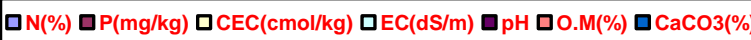

$\mathrm{LSD}_{0.05}(\mathrm{~N}=0.16, \mathrm{P}=1.05, \mathrm{CEC}=3.92, \mathrm{Ec}=0.12, \mathrm{pH}=0.22$,

$\mathrm{O} . \mathrm{M}=0.25, \quad \mathrm{CaCO}_{3}=1,01$ ) 


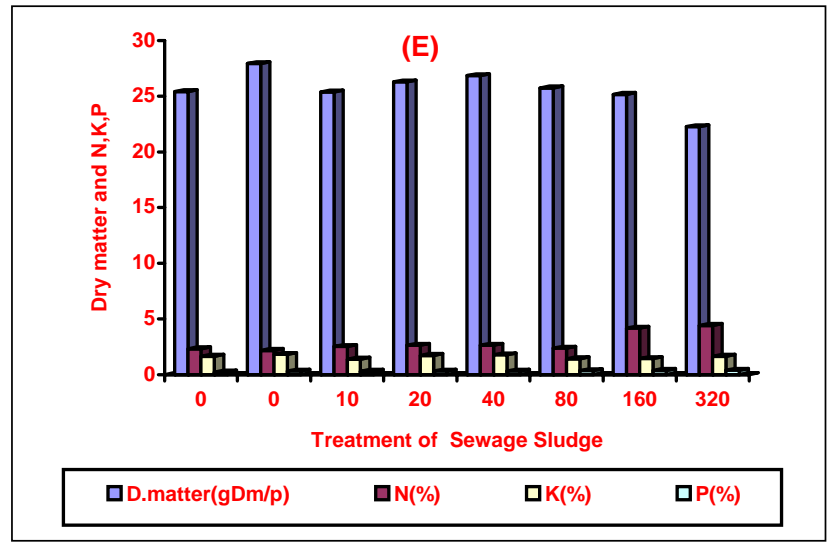

$\mathrm{LSD}_{\mathrm{o.05}}$ (D.matter=4.21,N=0.56 ,K= - , P=0.06 )

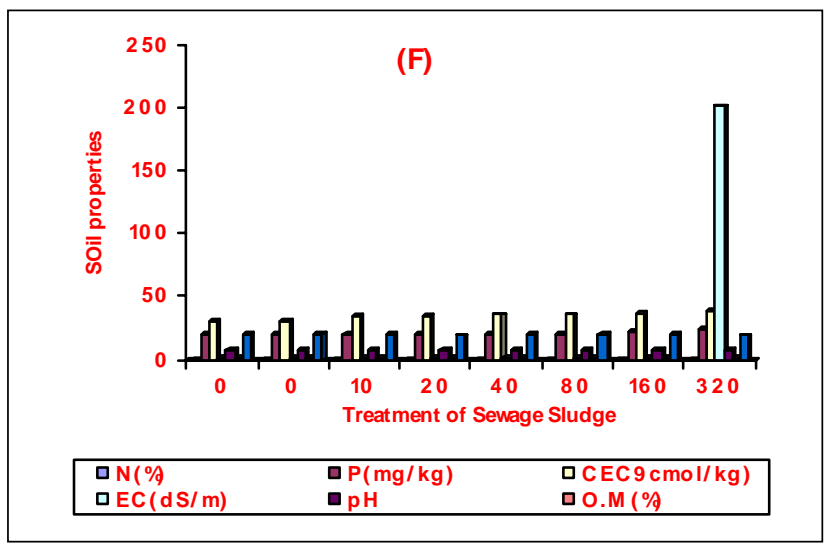

$\operatorname{LSD}_{0.05}(\mathrm{~N}=0.5, \mathrm{P}=2.51, \mathrm{CEC}=4.98, \mathrm{Ec}=0.15, \mathrm{pH}=0.22, \mathrm{O} . \mathrm{M}=0.27$ , $\mathrm{CaCO}_{3}=1.02$ )

\section{REFERENCES}

Abd - Alla, M.H ;Yan - Feng ; S.Schubert (1999) : Effect of sewage sludge application on Nodulation, nitrogen fixation, and plant growth of Faba bean, Soybean and lupin. Angewandte- Botanik, Germany.73(3/4):69-75

Aljunied,A.M(2007):Utilization of treated sewage water in irrigation and its effect on some soil physical,chemical characteristics and Sorghum fordder

productivity.Bulletin of Faculty of Agriculture,Cairo Unversity,58 (4):299-306.

Akdeniz,H;I.Yilmaz;M.A.Bozkurt;B.Keskin (2006): The effects of sewage sludge and nitrogen applications organic Sorghum growth (Sorghum Vulgare L.) in Van-

Turkey. Polish. Journal of Environmental studies. 15(1):1926.

Arden, D. A (1977) : The agricultural use sewage sludge.In: R. C.Loehr (ed) land as a waste management alternative. Springer-Verlag, Berlin, pp: 583-603.
Bremner,J.M(1965):Total nitrogen.In methodsof soil analysispart (2);(c.a.Blak,Ed),. American Society of agronomy,Madison,Wis., 1145-1178.

Chapman.H.D;(1965):Methods of soil analysis part (2). Chemical microbiological properties. Ed. C.A. Black.Amer.soc.of Agron.Inc.Publ.Agron.Series No:9, Medison,Wis, USA.

Chaussod, R;J.C. Germon; G.Catroux (1978): Determination de la fertilisante des boues residuaires.Aptutude a liberer lazote.Ministe re de l'environement et du cadre de vie.Convention détude n.74050(in French).

Dahdoh,M.S.A;F.A.Hassan(1997):Combined effect of sewage sludge and saline water irrigation on growth and elements composition of broad bean. Egyptain Journal of soil science.37(2):189-204.

Doran, J. W ; Parkin,T. B (1994) : Defining and assessing soil quality. In: Doran,

J.W;Coleman,D.C;Bezdicek,D.F;Stawart,B.A;(Eds). Defining soil quality for sustainable environment ,soil science soc. Am.special publication .No:35.soil science society of America, Madison,WI,pp:3-21.

Dowdy, R.H; W.E. Larson; J.M.T itrud;J.J.Latterell (1978): Growth and metal uptake of snap beans grown on sewage sludge amended soil.A four year field study. J.Environ.Qual.7:252-257.

Duncan, D.B. (1955). Multiple range and multiple F-test. Biometrics 11: 1-24.

Gomez, K.A. and Gomez, A.A. (1984). Statistical procedures for agricultural Res. $2^{\text {nd }}$ ed. Wiley, New York.

Heckman,J.R;J.S.Angle;R.L.Chaney

(1986):Soybean nodulation and nitrogen fixation on soil previously amended with sewage sludge. Bio.fertil.soils,2:181185.

Heckman,J.R;J.S.Angle;R.L.Chaney (1987):Rsidual effects of sewagw sludge on soybean :I,Accumulation of heavy metals.J.Environ.Qual.16:113-114.

Jackson,M.L (1973): soil chemical analysis.Prentice Hall Inc.Eng.Cliffs.U.S.A.

Johnson,C.M;A.Ulrich (1959): Analytical methods for use in plant analysis II.California Agri.Exp.Sta.Bull.766.

Lindsay,W.I;W.A.Norwell (1978):Development of a DTPA soil test for Zn,Fe,Mn,and Cu.soil sci.Am.J.42:421-428.

Murphy and Riley (1962): A modified single solution method for the determination of phosphate in natural waters.Anal.Chem.Acta,27:31-36.

Olsen, S.R; V.Cole; F.S. Watanabe; L.B. Dean (11965):Estimation of available phosphorus in soils by extraction with sodium bicarbonate.U.S.Dept.of Agr.939.Washingt,D.C. 
Omran,M.S;T.M.Waly (1988): Effect of sewage irrigation on yield three components heavy metals accumulation in navel orage trees.Biol.Wastes.23:17-24.

Page , A.L . ; R.H. Miller ; D.R. Keeney (1982) : Methods of soil analysis. Part 2: Chemical and microbiological properties. Second Edition. Agron. J. 9:2.

Parate,C;.Denaix;J.Leveque;R.Chaussod;F.Andreux (2007):The organic carbon derived from sewage sludge as a key parameter determining the fate of trace metals.Chemosphere.69(4):636-643.

Pluquet,E (1984): Die bodentung des tangehaltes und des $\mathrm{pH}$-wertes fu die schwermetalefnahme einiger kuhurrflanzen aus kontaminierten bonen,UBA Texte 40,Berlin.

Rabie,M.H;A.Y.Negm;M.M.Eleiwa;M.F.Abdel-Sabour (1997):Influence of two sewage sludge sources on Faba bean abd sorghum plants growth and elements uptake.Egyptain Journal of soil science.37(4):425-435.

Richards,L.A.,ed.(1954):Diagnosis and improvement of saline and alkali soils.U.S.D.A.Handbook 60.

Roberts,J.A;W.L.Daniels;J.C.Bell;D.C.Martens (1988):Tall rescue production and nutrient state on southwest Virginia mine soils.J.Environ .Qual.17:55-62.
Sanders,J.R.;A.Trevor;B.T.Christensen 1986):Extractability and bioavailability of $\mathrm{Zn}, \mathrm{Ni}, \mathrm{Cd}$,and $\mathrm{Cu}$ in three Danish soils sampled 5 years after application of sewage sludge.J.sci.Food Agric.37:1155-1164

Serna,M.D;F.Pomares (1992):Indexes of assessing N availability in sewage sludge.Plant soil.139:15-21.

Sommers,L.E (1977): Chemical Composition of sewage sludge and analysis of their potential use as fertilizer.J.Environ.Qual.6:225-232.

Suss, A (1979):Nitrogen availability in sewage sludge.In Concerted Action E.E.C.Treatment and use of sewage sludge.Cost project.68 bis,Dison.

Yeledhalli,N.A;S.S.Prakash;M.V.Ravi (2007):Trace element mobility in cool fly ash and sewage sludge amended soils.Environment and Ecology.25s (Special 4):990993).

Zucconi,F;M.De Bertoldi (1987);Compost specifications for the production and characterization of compost from municipal solid waste.In compost:Production,quality and use ,E.d.M.De Bertoldi, M.P. Ferranti, P.L.Hermite,Zucconi.F.,p.30-51, Elsveir Applied science, New York. 